\title{
Distinct Populations of Spinal Cord Lamina II Interneurons Expressing G-Protein-Gated Potassium Channels
}

\author{
Cheryl L. Marker, ${ }^{1}$ Rafael Luján, ${ }^{2}$ José Colón, ${ }^{1}$ and Kevin Wickman ${ }^{1}$ \\ ${ }^{1}$ Department of Pharmacology, University of Minnesota, Minneapolis, Minnesota 55455, and ${ }^{2}$ Facultad de Medicina, Centro Regional de Investigaciones \\ Biomédicas, Universidad de Castilla-La Mancha, 02006 Albacete, Spain
}

\begin{abstract}
Noxious stimuli are sensed and carried to the spinal cord dorsal horn by A $\delta$ and C primary afferent fibers. Some of this input is relayed directly to supraspinal sites by projection neurons, whereas much of the input impinges on a heterogeneous population of interneurons in lamina II. Previously, we demonstrated that G-protein-gated inwardly rectifying potassium (GIRK) channels are expressed in lamina II of the mouse spinal cord and that pharmacologic ablation of spinal GIRK channels selectively blunts the analgesic effect of high but not lower doses of intrathecal $\mu$-opioid receptor (MOR) agonists. Here, we report that GIRK channels formed by GIRK1 and GIRK2 subunits are found in two large populations of lamina II excitatory interneurons. One population displays relatively large apparent whole-cell capacitances and prominent GIRK-dependent current responses to the MOR agonist [D-Ala ${ }^{2}, N-\mathrm{MePhe}^{4}, \mathrm{Gly}^{-\mathrm{ol}^{5}}{ }^{5}$-enkephalin (DAMGO). A second population shows smaller apparent capacitance values and a GIRK-dependent response to the GABA $\mathrm{B}_{\mathrm{B}}$ receptor agonist baclofen, but not DAMGO. Ultrastructural analysis revealed that GIRK subunits preferentially label type I synaptic glomeruli, suggesting that GIRK-containing lamina II interneurons receive prominent input from $\mathrm{C}$ fibers, while receiving little input from A $\delta$ fibers. Thus, excitatory interneurons in lamina II of the mouse spinal cord can be subdivided into different populations based on the neurotransmitter system coupled to GIRK channels. This important distinction will afford a unique opportunity to characterize spinal nociceptive circuitry with defined physiological significance.
\end{abstract}

Key words: knock-out; opioid; GABA; baclofen; Kir3; substantia gelatinosa

\section{Introduction}

Most nociceptive information is brought to the spinal cord by fine-caliber $\mathrm{A} \delta$ and $\mathrm{C}$ primary afferent fibers (PAFs) that terminate in the superficial dorsal horn (SDH) (Julius and Basbaum, 2001). The SDH can be subdivided into two distinct laminas (laminas I and II) (Millan, 1999). Lamina I contains the cell bodies of ascending projection neurons that relay pain and temperature information to supraspinal structures. The roles of lamina II neurons are less clear, but they are thought to integrate PAF input and ultimately modify the output of ascending projection neurons in lamina I and in deeper laminas (Rethelyi and Szentagothai, 1969; Kumazawa and Perl, 1978; Light et al., 1979; Millan, 1999).

Lamina II can be subdivided into inner (IIi) and outer (IIo) layers (Woodbury et al., 2000) and consists of heterogeneous populations of excitatory and inhibitory interneurons (Millan, 1999). Interneuron subtypes can be distinguished on the basis of morphology, neurotransmitter content, and receptor expression (Millan, 1999). For example, neurochemical markers of excita-

Received Aug. 24, 2006; revised 0ct. 12, 2006; accepted 0ct. 14, 2006.

This work was supported by National Institutes of Health Grants R01 MH61933 (K.W.), P50 DA011806 (K.W.), and T32 DA07234 (C.L.M.); Consejería de Sanidad Junta de Comunidades de Castilla-La Mancha (JCCM) Grant SAN-04008-00 (R.L.); and Educacion y Ciencia JCCM Grant PAI05-040 (R.L.).

Correspondence should be addressed to Kevin Wickman, Department of Pharmacology, University of Minnesota,

6-120 Jackson Hall, 321 Church Street South East, Minneapolis, MN 55455. E-mail: wickm002@umn.edu.

C. L. Marker's present address: Algos Therapeutics, Inc., 1246 University Avenue West, St. Paul, MN 55104.

DOI:10.1523/JNEUROSCI.3693-06.2006

Copyright $\odot 2006$ Society for Neuroscience ～0270-6474/06/2612251-09\$15.00/0 tory interneurons include glutamate, substance $\mathrm{P}$, and vasoactive intestinal peptide, whereas receptors found predominantly in excitatory interneurons in lamina II include the AMPA subtype of ionotropic glutamate receptor (containing GluR2 and GluR3 subunits) and the $\mu$-opioid receptor (MOR) (Todd and Spike, 1993; Arvidsson et al., 1995; Spike et al., 1998, 2002). At present, little is known about the functional relevance of specific interneuron subtypes.

Recently, we found that the G-protein-gated inwardly rectifying $\mathrm{K}^{+}$(GIRK) channel subunits GIRK1 and GIRK2 were expressed in the SDH of the mouse spinal cord and were enriched in postsynaptic membranes in lamina IIo (Marker et al., 2005). Significant cellular and subcellular overlap between GIRK subunits and the MOR was observed in lamina IIo, suggesting a direct contribution of spinal GIRK channels to opioid inhibition and analgesia. GIRK1 knock-out and GIRK2 knock-out mice, as well as wild-type mice given intrathecal injections of the GIRK channel blocker tertiapin, exhibited thermal hyperalgesia and blunted analgesic responses to intrathecal morphine and the MOR-selective agonist $\left[\mathrm{D}-\mathrm{Ala}^{2}, \mathrm{~N}\right.$-MePhe ${ }^{4}, \mathrm{Gly}^{-\mathrm{ol}^{5}}{ }^{5}$-enkephalin (DAMGO) (Marker et al., 2004, 2005). Interestingly, GIRK channels were found to make a dose-dependent contribution to the analgesic effect of MOR agonists, such that the effect of high but not lower doses of opioid agonist was selectively blunted after the pharmacologic or genetic ablation of spinal GIRK channels.

Both pharmacologic and genetic approaches to GIRK channel ablation argue that spinal opioid analgesia can be dissected into 
GIRK-dependent (high-dose) and GIRK-independent (lowdose) components. Here, we used cell biological and electrophysiological approaches to probe the neuron types in lamina IIexpressing GIRK channels and applied ultrastructural techniques to examine the nature of the afferent input to GIRK-containing neurons in lamina II. By identifying the cell types and signaling pathways to which spinal GIRK channels contribute, it will become feasible to correlate behavioral-, neuroanatomical-, and molecular-level observations in this otherwise intractable neuron population.

\section{Materials and Methods}

Drugs and reagents. DAMGO and naloxone hydrochloride dihydrate were purchased from Sigma (St. Louis, MO). Baclofen $[R-(+)-\beta$ (aminomethyl)-4-chlorobenzenepropanoic acid hydrochloride] and [S- $\left.\left(R^{*}, R^{*}\right)\right]$-[3-[[1-(3,4-dichlorophenyl)ethyl] amino]-2-hydroxypropyl] ([3,4]-cyclohexylmethyl) phosphinic acid (CGP54626) were purchased from Sigma and Tocris (Ellisville, MO), respectively. All drugs were dissolved in $0.9 \%$ saline in high-concentration stocks, divided into single-use aliquots, and stored at $-20^{\circ} \mathrm{C}$.

Animals. All animal use was reviewed and approved by the Institutional Animal Care and Use Committee of the University of Minnesota. Efforts were made to minimize the pain and discomfort of the animals throughout the study. Adult mice (9-11 weeks old) were housed on a $12 \mathrm{~h}$ light/dark cycle, with food and water available ad libitum. The generation of GIRK knock-out mice was described previously (Signorini et al., 1997; Bettahi et al., 2002; Torrecilla et al., 2002; Koyrakh et al., 2005). The GIRK null mutations were backcrossed through at least 12 rounds against the C57BL/6 mouse strain before beginning this study.

Immunohistochemistry. Adult wild-type C57BL/6 and congenic GIRK knock-out mice were anesthetized and subjected to an established $4 \%$ paraformaldehyde-based transcardial perfusion protocol (Marker et al., $2004,2005)$. Spinal cord tissue was extracted, and the lumbar enlargement was dissected and flash-frozen onto chucks. Thin $(15 \mu \mathrm{m})$ sections were made by cryostat and affixed to glass slides for immunostaining. Sections were incubated overnight at $4^{\circ} \mathrm{C}$ with antibodies directed against GIRK1 or GIRK2 subunits $(0.5-2 \mu \mathrm{g} / \mathrm{ml}$; Alomone Labs, Jerusalem, Israel) and MOR (0.5-2 $\mu \mathrm{g} / \mathrm{ml}$; Millipore, Bedford, MA), $\mathrm{GABA}_{\mathrm{B}(1 \mathrm{a} / \mathrm{b})}$ (code B17, 0.5-2 $\mu \mathrm{g} / \mathrm{ml}$; generously supplied and extensively characterized by Dr. Ryuichi Shigemoto, National Institute for Physiological Sciences, Myodaiji, Okazaki, Japan) (Kulik et al., 2003; Lopez-Bendito et al., 2004; Lujan et al., 2004; Panzanelli et al., 2004; Lujan and Shigemoto, 2006), or GluR2/3 (0.5-2 $\mu \mathrm{g} / \mathrm{ml}$; Millipore). Sections were washed with PBS containing $0.1 \%$ Triton X-100, incubated for $1 \mathrm{~h}$ at room temperature with fluorescent-tagged secondary antibodies, washed again with PBS, dehydrated with ethanol solutions of increasing concentration, cleared with xylenes, and coverslipped with DPX (Fluka, Ronkonoma, NY).

Immunofluorescence was analyzed using a Leitz (Wetzlar, Germany) DMRB microscope with epifluorescent illumination. Brightness and contrast were adjusted for the entire frame; no isolated part of a frame was modified in any way. Double-labeled sections were scanned by the simultaneous application of two excitation wavelengths. The intensity of each laser was optimized for the sections from each panel of mice and combination of antibodies, and all parameters were kept constant for sections from a given panel of mice. A semiquantitative analysis of colabeled cells was performed in lamina IIo of the spinal cord using three panels of adult wild-type mice. Cell bodies showing immunoreactivity for GluR2/3, MOR, or GABA $\mathrm{B}_{\mathrm{B}(\mathrm{a} / \mathrm{b})}$ were identified and counted. Subsequently, the presence or absence of GIRK1 or GIRK2 in the markerpositive cell bodies was assessed at a high magnification $(100 \times$ objective). Assignment of overlap in each instance was based on the conservative interpretation of two individuals after evaluation of a complete $z$-series of images spanning each neuron evaluated.

GIRK subunit immunoprecipitation and immunoblotting. Spinal cord tissue was harvested from adult wild-type and GIRK knock-out mice and homogenized on ice in a buffer containing $320 \mathrm{~mm}$ sucrose and $4 \mathrm{~mm}$ HEPES, pH 7.4, supplemented with proteinase inhibitors (in $\mu \mathrm{g} / \mathrm{ml}: 10$ aprotinin, 1 pepstatin, 3 leupeptin, and 10 PMSF). Samples were centrifuged at $1000 \times g$ for $10 \mathrm{~min}$ at $4^{\circ} \mathrm{C}$ to remove nuclei and large debris, and the supernatants were then centrifuged at $120,000 \times g$ for $30 \mathrm{~min}$ at $4^{\circ} \mathrm{C}$ to pellet membranes. Pelleted membranes were resuspended in solubilization buffer consisting of $10 \mathrm{~mm}$ HEPES, pH 7.5, $300 \mathrm{~mm} \mathrm{NaCl}, 1 \mathrm{~mm}$ EDTA, 1\% CHAPS [3-[(3-cholamidopropyl)dimethylammonio]-1propanesulfonate], and proteinase inhibitors. A custom-derived, affinity-purified GIRK2 rabbit polyclonal antibody, raised against a C-terminal peptide motif found in GIRK2A and GIRK2C isoforms (SSKLNQHAELETEEEEKN), was cross-linked to protein G-Sepharose beads ( $50 \mu \mathrm{g}$ of antibody per $20 \mu$ l beads) with $\mathrm{BS}^{3}$ (Bis[sulfocuccinimidyl] suberate; Pierce, Rockford, IL) according to the manufacturer's specifications, and the Sepharose was prepared for immunoprecipitation via four washes with solubilization buffer. Spinal cord membrane protein samples were incubated with cross-linked Sepharose for $1 \mathrm{~h}$ at $4^{\circ} \mathrm{C}$, followed by two washes in solubilization buffer and two washes with solubilization buffer lacking detergent. Immunoprecipitated proteins were eluted from the beads using $5 \%$ ammonium hydroxide, dried, and resuspended in $2 \%$ SDS before loading on $4-12 \%$ gradient gels for SDS-PAGE (NuPAGE; Invitrogen, Carlsbad, CA). SDS-PAGE and immunoblotting were performed using GIRK1 and GIRK2 antibodies (Alomone Labs) as described previously (Koyrakh et al., 2005).

Spinal cord slice electrophysiology. Transverse slices $(450 \mu \mathrm{M})$ from the lumbar enlargement of the spinal cords of adult (9- to 11-week-old) wild-type and GIRK knock-out mice were prepared in slicing solution containing the following (in $\mathrm{mM}$ ): 110 choline-Cl, $2.5 \mathrm{KCl}, 1.25$ $\mathrm{NaH}_{2} \mathrm{PO}_{4}-\mathrm{H}_{2} \mathrm{O}, 25 \mathrm{NaHCO}_{3}, 0.5 \mathrm{CaCl}_{2}-2 \mathrm{H}_{2} \mathrm{O}, 1.1 \mathrm{MgCl}_{2}$, and 11 glucose. The slicing solution was bubbled with $95 \% \mathrm{O}_{2} / 5 \% \mathrm{CO}_{2}$ and maintained at $4-8^{\circ} \mathrm{C}$. Slices were stored at room temperature for $\geq 1 \mathrm{~h}$ in artificial CSF (ACSF) containing the following (in mM): $119 \mathrm{NaCl}, 2.5$ $\mathrm{KCl}, 1 \mathrm{NaH}_{2} \mathrm{PO}_{4}, 26.5 \mathrm{NaHCO}_{3}, 1.3 \mathrm{MgSO}_{4}, 2.5 \mathrm{CaCl}_{2}$, and 11 glucose, bubbled with $95 \% \mathrm{O}_{2} / 5 \% \mathrm{CO}_{2}$. Lamina II neurons were visualized with an Olympus Optical (Tokyo, Japan) BX51WI microscope equipped with infrared optics. Membrane currents and potentials were measured with a Multiclamp 700A amplifier, Digidata 1320, and pCLAMP version 9 software (Molecular Devices, Union City, CA) and recorded directly onto a computer hard disk. Bath and drug solutions were perfused using a Dynamax peristaltic pump (Rainin, Woburn, MA). Bath and chamber temperatures were clamped at $32^{\circ} \mathrm{C}$ with a TC-344B Dual Automatic Temperature Controller (Warner Instrument Corporation, Hamden, CT). Borosilicate (4-6 M $\Omega$ ) pipettes were filled with the following (in $\mathrm{mm}$ ): $115 \mathrm{~K}$-gluconate, $20 \mathrm{KCl}, 1.5 \mathrm{MgCl}_{2}$, 0.1 EGTA, 5 HEPES, $2 \mathrm{Mg}$-ATP, 0.5 Na-GTP and 10 phosphocreatine, $\mathrm{pH}$ 7.4. ACSF bubbled with $95 \%$ $\mathrm{O}_{2} / 5 \% \mathrm{CO}_{2}$ served as the bath solution and was perfused at a rate of $1-2$ $\mathrm{ml} / \mathrm{min}$. All measured and command potentials related to these studies factor in a predicted $-15 \mathrm{mV}$ junction potential associated with this combination of solutions. Single-aliquot, high-concentration stocks of DAMGO, baclofen, naloxone, and CGP54626 were thawed and diluted in bath solution before experiments.

Immediately after establishment of whole-cell access to a lamina II neuron, resting membrane potentials were measured in current-clamp mode $(I=0)$. Subsequently, recording stability was assessed in voltageclamp mode $\left(V_{\text {hold }}=-60 \mathrm{mV}\right)$ over a $5-10 \mathrm{~min}$ interval. Holding current, apparent cell capacitance $\left(C_{\mathrm{M}}\right)$, input resistance $\left(R_{\mathrm{M}}\right)$, and access resistance $\left(R_{\mathrm{A}}\right)$ were extracted from the current response to $200 \mathrm{~ms}$ voltage steps from -60 to $-50 \mathrm{mV}$. $R_{\mathrm{A}}$ was determined by calculating the ratio of the voltage step to the peak current of the transient, relative to the baseline. $R_{\mathrm{M}}$ was calculated based on the change in steady-state current observed in response to the $10 \mathrm{mV}$ voltage step. $C_{\mathrm{M}}$ values were calculated by fitting the decay phase of the current transient with a monoexponential function and extracting the tau, given that $C_{\mathrm{M}}=\left[\left(R_{\mathrm{A}}+R_{\mathrm{M}}\right) /\right.$ tau]. These parameters were sampled every $10 \mathrm{~s}$ and monitored in real time using pCLAMP version 9 software. Cells exhibiting stable holding currents and stable and low $R_{\mathrm{A}}(15-30 \mathrm{M} \Omega)$ were challenged with DAMGO $(0.1-10 \mu \mathrm{M})$. If a positive response to DAMGO was noted (outward current increase of $\geq 5 \mathrm{pA}$ and concomitant decrease in $R_{\mathrm{M}}$ ), 10 $\mu \mathrm{M}$ naloxone was added to the bath. At the end of each experiment, cells were challenged with baclofen $(100 \mu \mathrm{M})$, whether they responded to 
DAMGO or not. If a positive response to baclofen was noted, the $\mathrm{GABA}_{\mathrm{B}}$ receptor antagonist CGP56246 $(10 \mu \mathrm{M})$ was applied.

Immunoelectron microscopy. Tissue was prepared for ultrastructural analysis using a pre-embedding approach as described previously (Koyrakh et al., 2005). Free-floating sections were incubated in $10 \%$ normal goat serum (NGS) diluted in Tris-buffered saline (TBS) for $1 \mathrm{~h}$ at room temperature. Sections were then incubated for $48 \mathrm{~h}$ at $4^{\circ} \mathrm{C}$ with primary antibodies (GIRK1 or GIRK2) at final concentrations of 1-2 $\mu \mathrm{g} / \mathrm{ml}$ and diluted in TBS/1\% NGS. GIRK subunit immunoreactivity was revealed with the silver-intensified immunogold reaction. Sections were incubated for $3 \mathrm{~h}$ at room temperature with goat anti-rabbit Fab fragments coupled to $1.4 \mathrm{~nm}$ of gold (Nanoprobes, Stony Brook, NY) or biotinylated goat anti-rabbit Fab fragments (Vector Laboratories, Burlingame, CA). All secondary antibodies were diluted 1:100 in TBS/1\% NGS. Sections were then washed with TBS and double-distilled water, followed by silver enhancement of the gold particles with an HQ Silver kit (Nanoprobes) for 8-10 min. The sections were washed in PBS and postfixed with $\mathrm{OsO}_{4}$ ( $1 \%$ in $0.1 \mathrm{~m}$ phosphate buffer), followed by block staining with uranyl acetate, dehydration in graded series of ethanol solutions, and flat embedding on glass slides in Durcupan resin (Fluka, Buchs, Switzerland). Regions of interest were cut at 70-90 nm using a Reichert Ultracut E ultramicrotome (Leica, Vienna, Austria). Ultrathin sections were mounted on 200-mesh nickel grids, and counterstaining was performed on drops of $1 \%$ aqueous uranyl acetate, followed by Reynolds's lead citrate. Unless otherwise stated, electron microscopic samples were obtained from three different mouse spinal cords, and three blocks of each animal were cut for electron microscopy.

Ultrastructural analysis was performed with a TEM-JEOL 100-CX electron microscope (JEOL, Peabody, MA). Electron photomicrographs were captured with a CCD camera (MegaView III; Soft Imaging System, Münster, Germany). Digitized electron images were modified for brightness and contrast with Adobe Photoshop version 7.0 (Adobe Systems, San Jose, CA). To assess the specificity of GIRK subunit antisera, corresponding sections from GIRK knock-out mice were processed in parallel.

Labeled structures were classified as axons, axon terminals, synapses, dendrites, or astrocytic processes based on morphological information in each section (Ribiero-da-Silva and Coimbra, 1982; Peters et al., 1991; Lu et al., 2002). Axons were identified by their lack of synaptic input, the presence of neurotubules and occasional vesicles, and, in rare instances, the presence of myelin (Abbadie et al., 2001). Axon terminals were identified by the presence of synapses and small round and/or large granular vesicles. Synapses were identified as parallel membranes separated by widened clefts that are associated with membrane specializations. Synapses displaying a prominent density on the postsynaptic side were characterized as asymmetrical (putative excitatory), whereas synapses showing equivalent densities on both sides were characterized as symmetrical (putative inhibitory) (Peters et al., 1991). Smaller axon terminals that contained flattened vesicles and establish a single synapse were also identified in lamina II. These structures are thought to represent the terminal endings of intrinsic GABAergic interneurons ( $\mathrm{Lu}$ et al., 2002). Dendrites were identified by the presence of synaptic contacts, lack of small vesicles, diffuse filaments, and numerous mitochondria. Astrocytic processes were identified by their amorphous shape, lack of vesicles and synaptic contacts, and presence of glial microfilaments.

Glomeruli with clear morphological features containing dendrites positive for GIRK subunits were classified according to accepted criteria (Rethelyi and Szentagothai, 1969; Rethelyi et al., 1982; Ribiero-da-Silva and Coimbra, 1982; Gerke and Plenderleith, 2004). Type I glomeruli were identified by their large scalloped central termini and contacts with at least four or five dendrites, the presence of densely packed pleiomorphic synaptic vesicles, and the relative dearth of mitochondria. Type II glomeruli were identified by their larger and more regular contour, light axoplasm, numerous mitochondria, and homogeneous assortment of small, round vesicles. Type I glomeruli were also classified based on the absence (type Ia) or presence (type Ib) of dense-core synaptic vesicles, whereas type II glomeruli were also classified based on the presence (type IIa) or absence (type IIb) of neurofilaments in the central varicosity.

To establish the relative abundance of GIRK1 and GIRK2 immunoreactivity in the two types of spinal cord glomeruli, quantification of im- munolabeling was performed in lamina II from $60 \mathrm{~mm}$ coronal slices processed for pre-embedding immunogold immunohistochemistry. For each of five animals, three samples of tissue were obtained for preparation of embedding blocks (totaling 15 blocks). To minimize false negatives, electron microscopic serial ultrathin sections were cut and analyzed close to the surface of each block, because immunoreactivity decreased with depth. Blocks were cut on a tilt, resulting in sections with graded immunogold labeling. Because immunoreactivity decreased with depth, the quality of immunolabeling was estimated by selecting areas with optimal gold labeling at approximately the same distance from the cutting surface. All glomeruli included in the analysis were examined for consistency with regard to GIRK subunit labeling profile in three to four serial utrathin sections. Quantification was performed on three ultrathin sections chosen randomly from each block and animal. Randomly selected areas were then photographed from the selected ultrathin sections and printed, with a final magnification of $40,000 \times$.

Statistical analysis. Data are presented as the mean \pm SEM. Statistical analysis was performed with the SPSS (Chicago, IL) version 10 software. The $\chi^{2}$ analysis was used to assess the impact of genotype on the frequency of observed DAMGO and baclofen responses. The impact of DAMGO concentration on current responses in wild-type lamina II neurons, as well as the impact of genotype on the magnitude of agonistinduced currents, resting membrane potentials, and apparent capacitance values, were assessed with one-way ANOVA. Within-genotype comparisons of resting membrane potentials and apparent capacitance values involving the three agonist response profiles (DAMGO responders, baclofen but not DAMGO responders, and nonresponders) were also made with one-way ANOVA. When appropriate, Tukey's honestly significant difference post hoc test was used for pairwise comparisons. The level of significance was considered as $p<0.05$.

\section{Results}

We used an antibody colabeling strategy to gain insight into the cell type(s) expressing GIRK subunits in the spinal cord dorsal horn. Conditions for immunofluorescent detection of GIRK1 and GIRK2 subunits in mouse spinal cord tissue, including demonstrations of GIRK antibody specificity using tissue from knock-out mice, were described previously (Marker et al., 2005). The present analysis focused on the region of most prominent GIRK subunit staining, shown previously to be lamina IIo (Marker et al., 2005). Because the boundary between lamina IIo and lamina IIi is ambiguous, however, the tested region will be referred to conservatively as lamina II.

The hyperalgesia and blunted opioid analgesia seen in pharmacologic and genetic models of GIRK channel ablation suggested that spinal GIRK channels are expressed in pronociceptive circuitry (Marker et al., 2005). As such, we postulated that GIRK channels are found in excitatory interneurons in lamina II. Indeed, $>90 \%$ of lamina II neurons labeled by an antibody recognizing the AMPA glutamate receptor subunits GluR2 and GluR3 (GluR2/3), shown previously to mark excitatory interneurons in lamina II (Spike et al., 1998), were also positive for GIRK1 (93\%, 13 of 14) or GIRK2 (91\%, 42 of 46) (Fig. 1). Conversely, $>90 \%$ of lamina II neurons expressing GIRK subunits also were immunopositive for GluR2/3. Thus, GIRK1 and GIRK2 subunits are primarily codistributed with GluR2/3 in lamina II neurons of the mouse spinal cord.

We next examined the cellular overlap between GIRK subunits and two Gi/o-coupled receptors $\left(\mathrm{MOR}\right.$ and $\mathrm{GABA}_{\mathrm{B}}$ ) linked to spinal antinociception (Millan, 1999). Antibodies directed against $\mathrm{MOR}$ and the $\mathrm{GABA}_{\mathrm{B}(1 \mathrm{a} / \mathrm{b})}$ receptor subunit were characterized previously and shown to be specific as judged by the complete loss of labeling in CNS sections from the appropriate knockout mouse (Marker et al., 2004, 2005; Lujan and Shigemoto, 2006). As shown previously for MOR (Marker et al., 2005), immunoreactivity for $\mathrm{GABA}_{\mathrm{B}(1 \mathrm{a} / \mathrm{b})}$ (Fig. $2 \mathrm{~A}$ ) was pronounced in the 
$\mathrm{SDH}$, clearly encompassing the region of prominent GIRK subunit labeling (Fig. $2 A-C)$. Most labeling for MOR and $\mathrm{GABA}_{\mathrm{B}(\mathrm{la} / \mathrm{b})}$ was found in a dense neuropil (Fig. 2D-I), consistent with previous observations for both GIRK1 and GIRK2 (Marker et al., 2004, 2005). Nevertheless, specific labeling for the two receptors could be detected in cell bodies; the presence or absence of GIRK subunits was then evaluated in cell bodies immunopositive

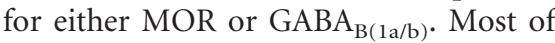
the lamina II neurons immunoreactive for MOR showed positive labeling for GIRK1 (74\%, 26 of 35) or GIRK2 (82\%, 32 of 39). Similarly, most of the $\mathrm{GABA}_{\mathrm{B}(\mathrm{la} / \mathrm{b})^{-}}$ positive neurons studied in lamina II displayed labeling for either GIRK1 (76\%, 29 of 38$)$ or GIRK2 $(88 \%, 37$ of 42$)$. The cellular overlap between MOR and $\mathrm{GABA}_{\mathrm{B}(1 \mathrm{a} / \mathrm{b})}$ in lamina II was slightly less striking, with only half $(51 \%, 18$ of 35$)$ of the neurons displaying immunoreactivity for both $\mathrm{GABA}_{\mathrm{B}(\mathrm{la} / \mathrm{b})}$ and MOR antibody.

To determine whether GIRK channels are direct downstream targets of $\mathrm{MOR}$ and $\mathrm{GABA}_{\mathrm{B}}$ receptors in lamina II neurons, we used slice electrophysiology to measure currents evoked by the MOR agonist DAMGO and the $\mathrm{GABA}_{\mathrm{B}}$ receptor agonist baclofen in lamina II neurons from the lumbar enlargement of adult wild-type and GIRK knock-out mice. Although neurons found in the most superficial aspect of the translucent region of the section (presumptive lamina IIo neurons) were targeted for evaluation, they will be referred to throughout as lamina II neurons.

After determination of resting membrane potentials, lamina II neurons were monitored in voltage-clamp mode and challenged with the bath application of a single DAMGO concentration $(0.1-3 \mu \mathrm{M})$. Consistent with previous reports in the rat spinal cord (Schneider et al., 1998; Eckert and Light, 2002), 40\% (42 of 103) of wild-type lamina II neurons exhibited outward currents and concomitant decreases in input resistance after DAMGO application (Fig. 3A). Evoked currents exhibited inward rectification and sensitivity to 1 $\mathrm{mM} \mathrm{Ba}^{2+}$ (data not shown), acute desensitization, and reversal by the opioid receptor antagonist naloxone $(10 \mu \mathrm{M})$. Maximal current responses were observed with $3 \mu \mathrm{M}$ DAMGO $(88 \pm 10$ $\mathrm{pA} ; n=12)$, and a concentration-response relationship was apparent $\left(F_{(3,33)}=5.0 ; p<0.01\right)$ (Fig. $3 B$ ). At higher DAMGO concentrations (e.g., $10 \mu \mathrm{M})$, evoked currents were not greater than seen at $3 \mu \mathrm{M}$, and these currents were not reliably reversed by naloxone (data not shown).

To establish the relevance of GIRK channels to the observed DAMGO-induced currents, we challenged lamina II neurons from GIRK1, GIRK2, and GIRK3 knock-out mice with $3 \mu \mathrm{M}$
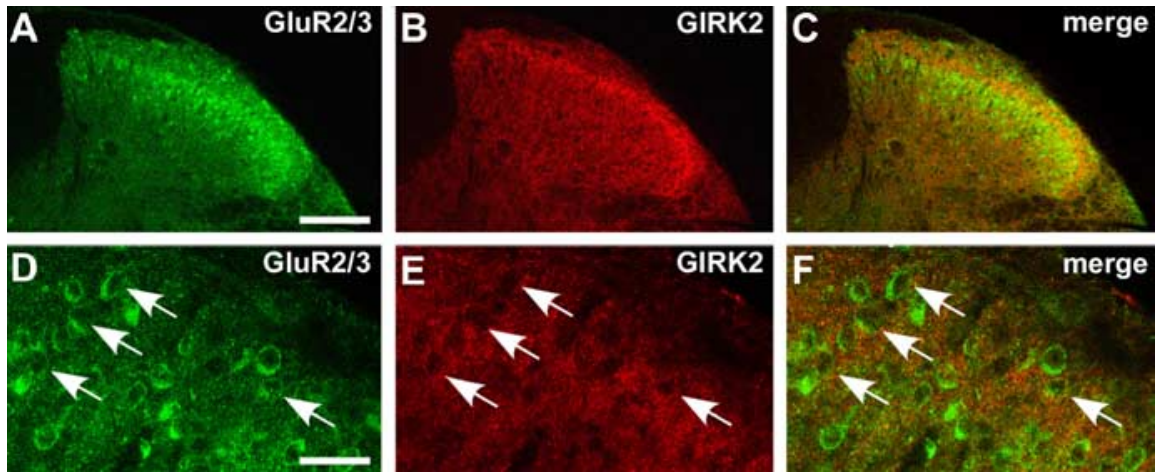

Figure 1. Expression of GIRK subunits in excitatory interneurons of lamina II. $\boldsymbol{A}-\boldsymbol{C}$, Low-magnification image of a transverse section $(15 \mu \mathrm{m})$ from the lumbar enlargement of a wild-type adult mouse spinal cord colabeled with antibodies directed against GIRK2 and the excitatory interneuron marker GluR2/3. Note that GIRK2 labeling is most prominent in a relatively thin band of the SDH (lamina Ilo). Specific GluR2/3 labeling is also seen in this region, but immunoreactivity for this marker is more prominent in inner lamina of the mouse SDH. $\boldsymbol{D}-\boldsymbol{F}$, High-magnification confocal image of GluR2/3 and GIRK2 subunit colabeling in lamina II. Arrows point to four cells that showed labeling for both GluR2/3 and GIRK2. Determination of cellular overlap was complicated by the overlapping but distinct subcellular distributions of GIRK subunits and GluR2/3; assignment of overlap in each instance was based on the judgment of two individuals after evaluation of a complete z-series of images spanning each neuron evaluated. Data presented are representative of experiments involving tissue from three different panels of adult wild-type mice. Similar data were obtained in GIRK1 colabeling studies. Scale bars: (in $\boldsymbol{A}) \boldsymbol{A}-\boldsymbol{C}, 75 \mu \mathrm{m}$; (in $\boldsymbol{D}) \boldsymbol{D}-\boldsymbol{F}, 30 \mu \mathrm{m}$.
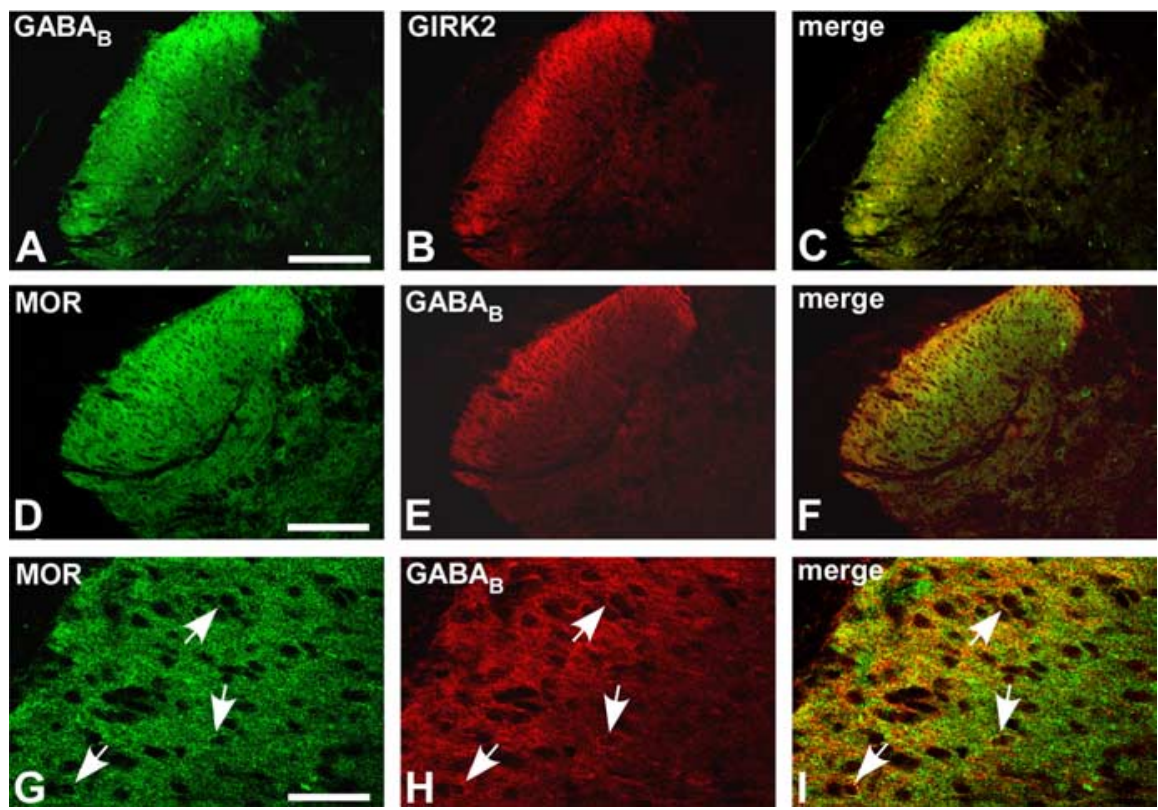

Figure 2. Overlap between GIRK subunits, MOR, and the $G A B A_{B}$ receptor in lamina II. $\boldsymbol{A}-\boldsymbol{C}$, Low-magnification image of a transverse section $(15 \mu \mathrm{m})$ of the lumbar enlargement from a wild-type adult mouse spinal cord colabeled with antibodies directed against GIRK2 and the $\mathrm{GABA}_{\mathrm{B}(1 \mathrm{a} / \mathrm{b})}$ subunit. The $\mathrm{GABA}_{\mathrm{B}(1 \mathrm{a} / \mathrm{b})}$ antibody shows intense labeling in the superficial layers of the dorsal horn, encompassing the region of prominent GIRK subunit immunoreactivity. $\boldsymbol{D}-\boldsymbol{F}$, Low-magnification image of MOR and $\mathrm{GABA}_{\mathrm{B}(1 \mathrm{a} / \mathrm{b})}$ colabeling in lamina II. Both receptors show prominent expression in the superficial layers of the dorsal horn, with less intense labeling seen in inner layers. $\mathbf{G}-\mathbf{I}$, High-magnification confocal image of $M O R$ and $\mathrm{GABA}_{\mathrm{B}(1 \mathrm{a} / \mathrm{b})}$ subunit colabeling in lamina II. Arrows point to three cells that exhibited labeling for both receptor types. Data presented are representative of experiments involving tissue from three different adult wild-type mice. Scale bars: (in $\boldsymbol{A}) \boldsymbol{A}-\boldsymbol{C}$, (in $\boldsymbol{D}) \boldsymbol{D}-\boldsymbol{F}$, $75 \mu \mathrm{m}$; (in $\boldsymbol{G}$ ) $\mathbf{G}-\boldsymbol{I}, 30 \mu \mathrm{m}$.

DAMGO. DAMGO-induced currents observed in lamina II neurons from GIRK1 knock-out $(48 \pm 11 \mathrm{pA} ; n=5 ; p=0.16)$ and GIRK2 knock-out $(22 \pm 5 \mathrm{pA} ; n=4 ; p<0.05)$ mice were muted (Fig. 3C). In addition, far fewer lamina II neurons from GIRK1 knock-out ( 5 of $43,12 \%$; $p<0.001$ ) and GIRK2 knock-out ( 4 of $53,8 \% ; p<0.001)$ mice responded to DAMGO compared with wild type. In contrast, a role for GIRK3 in spinal GIRK channel formation was not evident, because DAMGO-induced currents measured in lamina II neurons from GIRK3 knock-out mice 

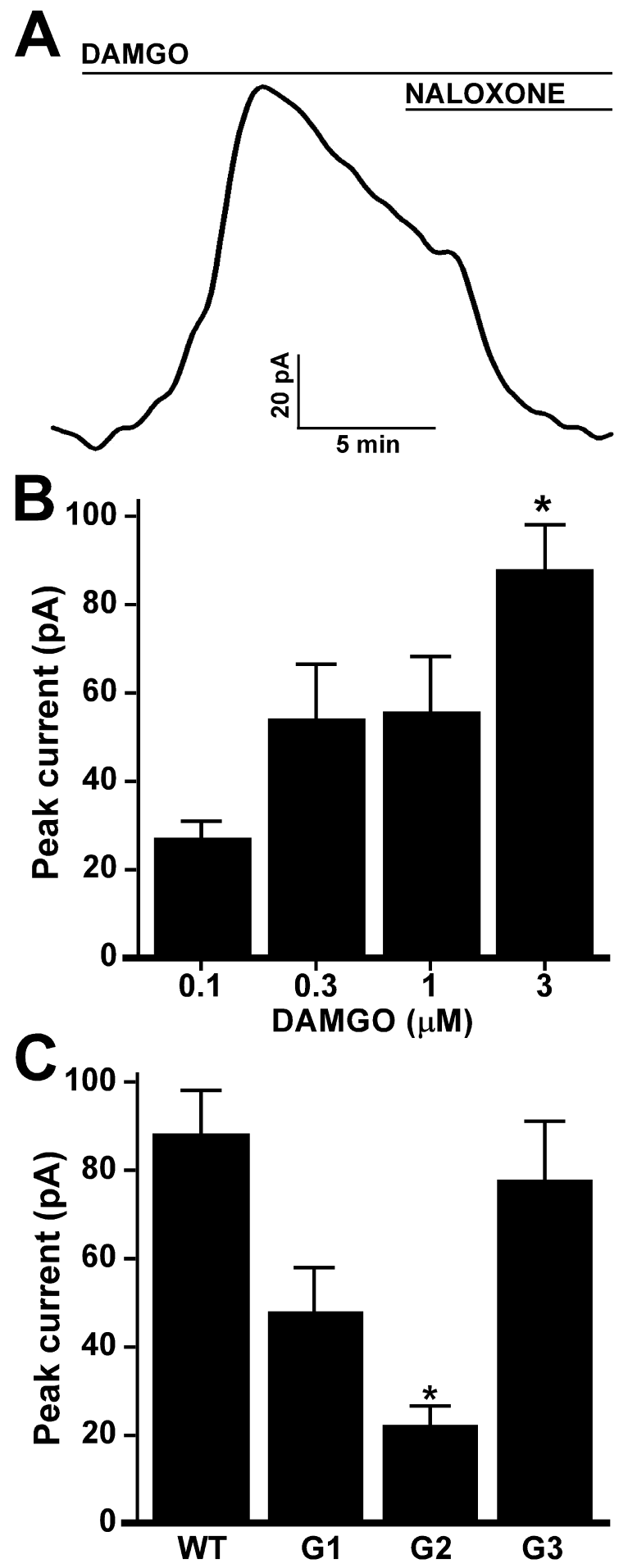

Figure 3. DAMG0-induced currents in wild-type and GIRK knock-out lamina II neurons. Whole-cell currents were measured at a holding potential of $-60 \mathrm{mV}$. A, Typical profile of an outward current evoked by $3 \mu \mathrm{m}$ DAMG0, and its subsequent reversal by naloxone (10 $\mu \mathrm{M})$, seen in a lamina II neuron from a wild-type mouse. Currents were accompanied by corresponding decreases in membrane resistance (data not shown). $\boldsymbol{B}$, The concentration-response relationship between DAMGO and evoked currents in wild-type lamina II neurons $\left(F_{(3,33)}=5.0\right.$; $p<0.01)$. At each concentration, data from $7-12$ responding cells were used to compile an average. ${ }^{*} p<0.05$ versus $0.01 \mu \mathrm{m}$ DAMG0. C, Effect of GIRK subunit ablation on peak current evoked by $3 \mu \mathrm{m}$ DAMG0. A significant impact of genotype was observed $\left(F_{(3,29)}=4.2 ; p<\right.$ 0.05 ), with DAMG0-induced currents blunted in lamina II neurons from GIRK2 knock-out mice $(G 2 ; n=4)$. DAMG0-induced currents were also reduced in the responding neurons from GIRK1 knock-out mice $(\mathrm{G} 1 ; n=5)$ but not from GIRK3 knock-out mice $(\mathrm{G} 3 ; n=12) .{ }^{*} p<0.05$ versus wild type (WT). Error bars indicate SEM.

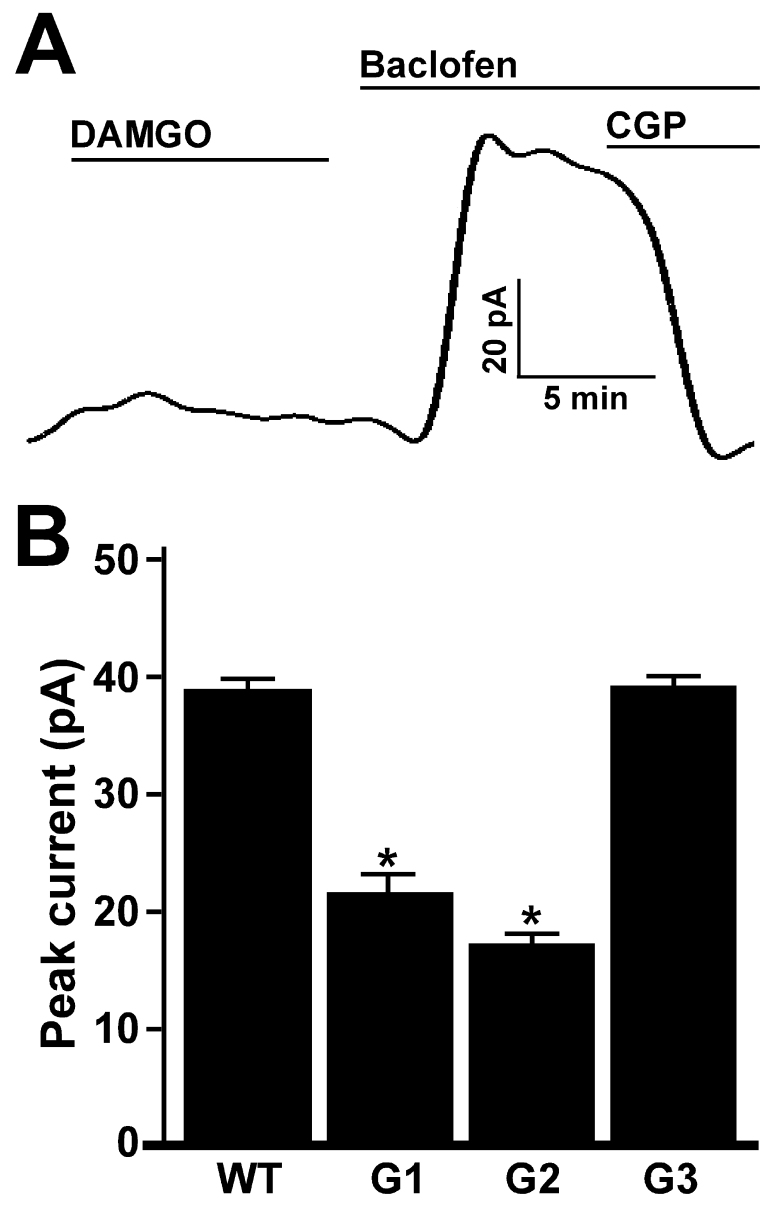

Figure 4. Baclofen-induced currents in wild-type and GIRK knock-out lamina II neurons. Whole-cell currents were measured at a holding potential of $-60 \mathrm{mV}$. A, Typical profile of a wild-type lamina II neuron that did not respond to DAMGO $(3 \mu \mathrm{M})$ but did show an outward current after the subsequent application of $100 \mu \mathrm{m}$ baclofen. The evoked current was reversed by the $\mathrm{GABA}_{B}$ receptor antagonist (GP54626 (CGP; $2 \mu \mathrm{m}$ ). Currents were accompanied by corresponding decreases in membrane resistance (data not shown). $\boldsymbol{B}$, Effect of GIRK subunit ablation on peak current evoked by $100 \mu \mathrm{m}$ baclofen. A significant impact of genotype was observed $\left(F_{(3,128)}=14.4 ; p<0.001\right)$. Baclofen-induced currents were significantly blunted in lamina II neurons from GIRK1 knock-out (G1; $n=20)$ and GIRK2 knock-out (G2; $n=16$ ) mice but not from GIRK3 knock-out (G3; $n=42$ ) mice. ${ }^{*} p<0.05$ versus wild type (WT). Error bars indicate SEM.

$(72 \pm 12 \mathrm{pA} ; n=12 ; p=0.66)$ were indistinguishable from wild-type mice (Fig. 3C). Furthermore, both the frequency (2 of 18 ) and magnitude $(35 \pm 25 \mathrm{pA} ; n=2)$ of the residual DAMGOinduced current seen in lamina II neurons from GIRK2/GIRK3 double knock-out mice were comparable to that seen in GIRK2 knock-out mice (data not shown).

Regardless of the whole-cell current response of the lamina II neurons to DAMGO, all neurons were challenged with the $\mathrm{GABA}_{\mathrm{B}}$ receptor agonist baclofen $(100 \mu \mathrm{M})$. Approximately half of the wild-type lamina II neurons that responded to DAMGO with an outward current and decreased input resistance responded similarly to baclofen (data not shown). Reponses to both agonists suggests that these lamina II neurons expressed both $\mathrm{GABA}_{\mathrm{B}}$ receptors and MOR. More surprising, however, was the observation that the vast majority (54 of 61) of wild-type lamina II neurons that did not show a DAMGO response did exhibit a baclofen-induced outward current ( $38 \pm 2 \mathrm{pA}$ ) (Fig. $4 A$ ) and concomitant decrease in input resistance. Furthermore, the impact of GIRK subunit ablation on the baclofen-induced 


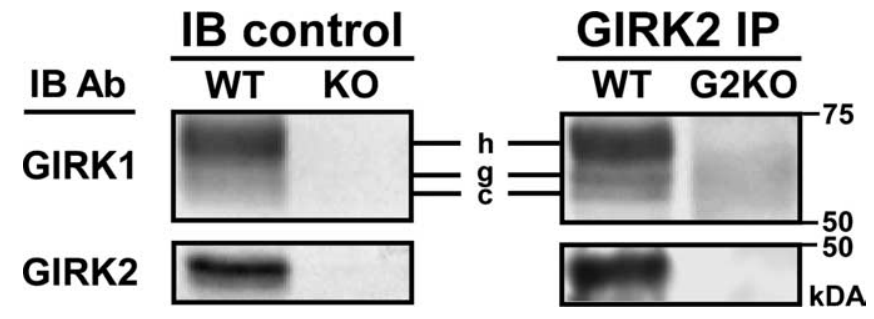

Figure 5. GIRK1 and GIRK2 form complexes in the mouse spinal cord. Left, Samples of wildtype and appropriate GIRK knock-out (KO) brain membrane proteins, included to demonstrate the specificities of the GIRK antibodies (Ab) used in the immunoblot (IB). Right, GIRK1 and GIRK2 immunoblots of proteins immunoprecipitated (IP) from wild-type and GIRK2 knock-out (G2KO) spinal cord membrane protein extracts using a custom-derived GIRK2 antibody. Note that GIRK2 was specifically immunoprecipitated from wild-type but not GIRK2 knock-out spinal cord membrane protein samples. Furthermore, GIRK1 was coimmunoprecitated in wild-type but not GIRK2 knock-out samples. GIRK1 immunoreactivity frequently appears as three distinct bands corresponding to heavily glycosylated (h), glycosylated (g), and unglycosylated (core; $\mathrm{c}$ ) versions of the GIRK1 protein (Krapivinsky et al., 1995). Data presented are representative of three different immunoprecipitation experiments involving three different wild-type and GIRK2 knock-out mouse panels. WT, Wild type.

responses was similar to that seen in the DAMGO-responsive neurons, with lamina II neurons from GIRK3 knock-out mice $(38 \pm 2 \mathrm{pA} ; n=42 ; p=1.0)$ showing normal responses and neurons from GIRK1 knock-out $(22 \pm 3$ pA; $n=20 ; p<0.001)$ and GIRK2 knock-out ( $16 \pm 1 \mathrm{pA} ; n=16 ; p<0.001)$ mice showing muted responses (Fig. $4 B$ ). Thus, normal whole-cell current responses of lamina II neurons to both DAMGO and baclofen are dependent on the presence of both GIRK1 and GIRK2.

To determine whether GIRK1 and GIRK2 subunits form complexes in the mouse spinal cord, immunoprecipitation experiments involving spinal cord membrane proteins were performed with a custom-derived GIRK2-specific polyclonal antibody. This antibody was able to specifically immunoprecipitate a $\sim 46 \mathrm{kDa}$ protein recognized by GIRK2-specific antibodies in immunoblotting experiments (Fig. 5). Furthermore, GIRK1 was specifically coimmunoprecipitated by the GIRK2 antibody, indicating that GIRK1 and GIRK2 complexes are present in spinal cord neurons. These data, together with their similar cellular and subcellular distributions, and the electrophysiological data presented above, argue strongly that GIRK1/GIRK2 heteromultimers underlie the GIRK-dependent component of the DAMGOand baclofen-induced currents in lamina II neurons of the mouse spinal cord.

Based on the functional characterization described above, wild-type lamina II neurons could be broadly classified as those responding to DAMGO (42 of 103 neurons), those responding to baclofen but not DAMGO (54 of 103 neurons), and those failing to respond to either agonist ( 7 of 103 neurons). Two clear correlations between agonist response profile and two properties of wild-type lamina II neurons were noted. First, wild-type lamina II neurons that failed to respond to either agonist were more depolarized at rest $(-65 \pm 3 \mathrm{mV} ; n=7 ; p<0.05)$ than lamina II neurons responding to DAMGO $(-73 \pm 1 \mathrm{mV} ; n=42)$ or baclofen $(-69 \pm 1 \mathrm{mV} ; n=54)$ (Fig. 6A). Correlations between agonist response profile and resting membrane potential were not observed, however, in lamina II neurons from GIRK1 knockout and GIRK2 knock-out mice, suggesting that channels formed by GIRK1 and/or GIRK2 contribute to the resting membrane potential differences observed between the agonist-responsive and nonresponsive wild-type lamina II neurons. Second, wildtype neurons responding to DAMGO exhibited significantly
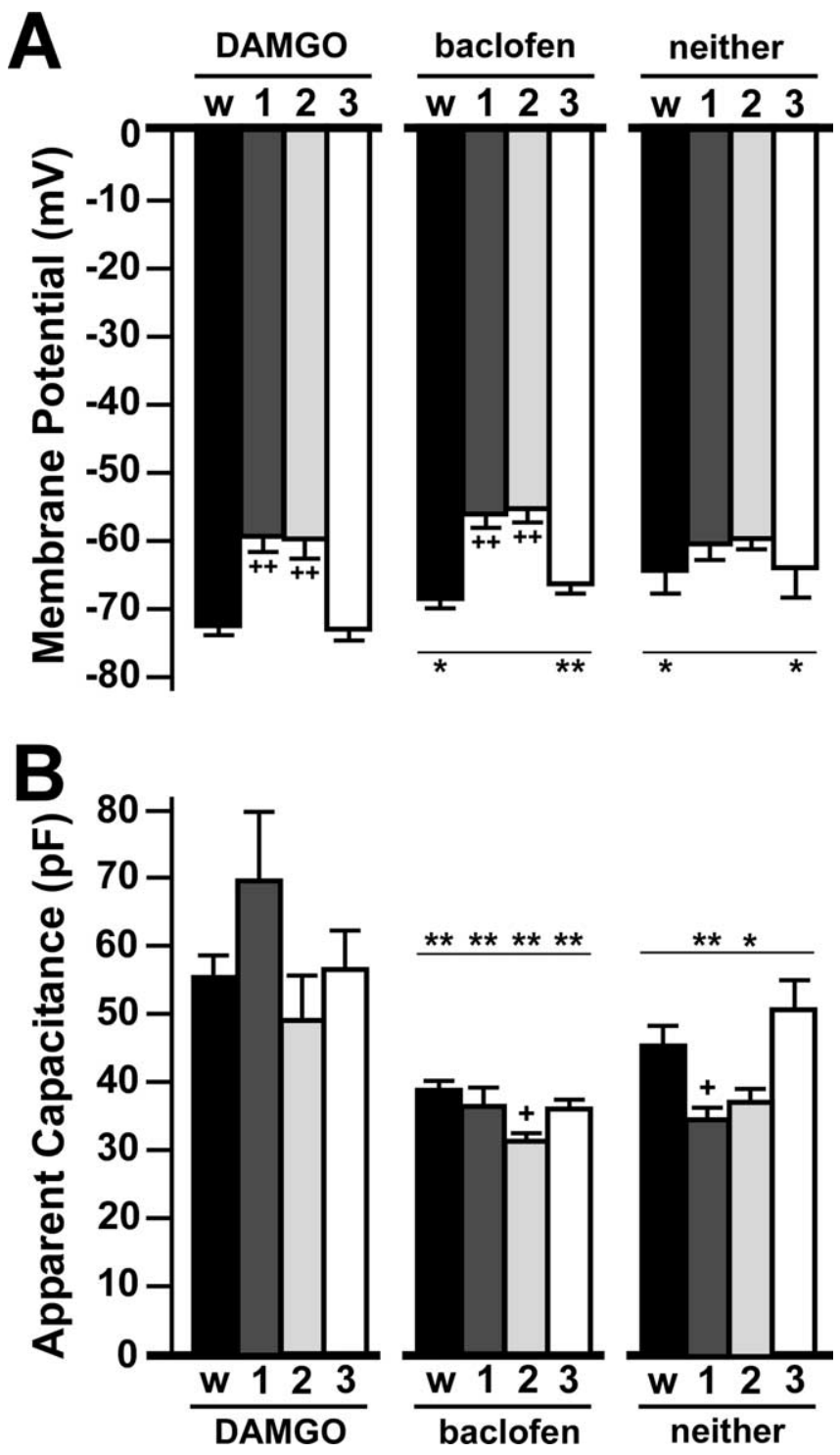

Figure 6. Correlations between agonist response profiles and properties of mouse lamina II neurons. $\boldsymbol{A}$, Membrane potentials of lamina II neurons plotted as a function of agonist response profile and genotype. DAMG0-responsive wild-type and GIRK3 knock-out lamina II neurons were relatively hyperpolarized compared with neurons of the same genotype with different agonist response profiles. Furthermore, DAMG0-responsive and baclofen-responsive GIRK1 knock-out and GIRK2 knock-out neurons were significantly depolarized compared with wildtype and GIRK3 knock-out groups. $\boldsymbol{B}$, The apparent capacitance values of lamina II neurons plotted as a function of agonist response profile and genotype. The DAMGO-responsive lamina II neurons in all genotypes exhibited significantly greater apparent capacitance values than the baclofen-responsive neurons. ${ }^{*} p<0.05$ and ${ }^{* *} p<0.01$ versus DAMGO (within-genotype group); ${ }^{+} p<0.05$ and ${ }^{++} p<0.01$ versus wild type (within-agonist group). Error bars indicate SEM. w, Wild type; 1, GIRK1 knock-out; 2, GIRK2 knock-out; 3, GIRK3 knock-out.

greater apparent capacitance values $(55 \pm 3 \mathrm{pF})$ than neurons responding to baclofen $(38 \pm 1 \mathrm{pF} ; p<0.001)$ (Fig. $6 B)$. The correlation between apparent cell capacitance and DAMGO sensitivity was also seen in lamina II neurons from each of the GIRK knock-out mice.

Our cell biological and electrophysiological data suggested that channels formed by GIRK1 and GIRK2 are found in multiple subpopulations of excitatory interneurons in lamina II of the mouse spinal cord, and that these channels are direct downstream targets in opioidergic and GABAergic signaling pathways. To understand how GIRK channels modulate nociception and 


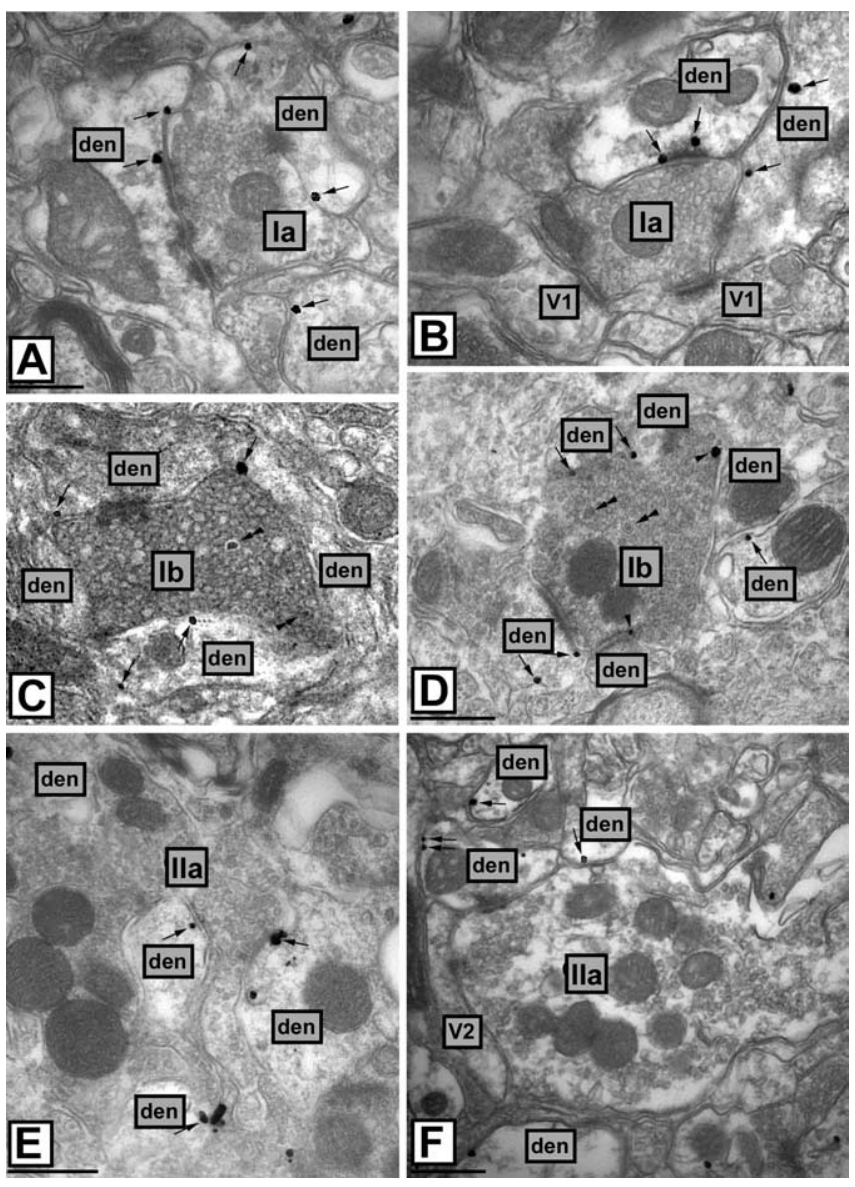

Figure 7. Characterization of synaptic glomeruli immunoreactive for GIRK subunits. Electron micrographs showing immunolabeling for GIRK1 and GIRK2 in type I and II glomeruli in lamina II of wild-type mice, as detected using a pre-embedding immunogold method. A, B, GIRK1 and GIRK2 immunoreactivity observed in type la glomeruli (la) along the extrasynaptic plasma membrane (arrows) of dendritic shafts postsynaptic to excitatory axon terminals. C, D, GIRK1 and GIRK2 immunoreactivity was also seen in type Ib glomeruli (Ib) along the extrasynaptic plasma membrane (arrows) of dendritic shafts postsynaptic to excitatory axon terminals. Type Ib glomeruli are distinguished by the presence of dense-core vesicles (double arrowheads). In both type la and type Ib glomeruli, a small fraction (15\%) of the GIRK2 immunoparticles were found at presynaptic sites (arrowheads). GIRK1 was never found at presynaptic sites. E, F, GIRK1 and GIRK2 subunits were also seen, albeit rarely ( $\sim 8 \%$ ) of type II glomeruli, and in these cases, morphological evidence suggested type lla structures (Ila). GIRK subunit labeling in type lla glomeruli was seen along the extrasynaptic plasma membrane (arrows) of dendritic shafts postsynaptic to excitatory axon terminals. A few immunoparticles for GIRK2 were also observed at presynaptic sites. Scale bars, $0.2 \mu \mathrm{m}$. den, Dendritic shafts; $\mathrm{V1}$, peripheral terminal containing a heterogeneous population of clear vesicles; V2, peripheral terminal with mostly flattened vesicles.

Table 1. Distribution of GIRK subunit labeling in lamina II synaptic glomeruli

\begin{tabular}{|c|c|c|c|c|c|c|}
\hline \multirow[b]{2}{*}{ Glomeruli } & \multicolumn{3}{|l|}{ GIRK1 } & \multicolumn{3}{|l|}{ GIRK2 } \\
\hline & Total & Number Positive & Frequency (\%) & Total & Number Positive & Frequency (\%) \\
\hline Type I & 83 & 74 & 89 & 87 & 79 & 91 \\
\hline la & & 44 & 59 & & 48 & 61 \\
\hline $\mathrm{lb}$ & & 30 & 41 & & 31 & 39 \\
\hline Type II & 79 & 6 & 8 & 81 & 7 & 9 \\
\hline lla & & 5 & 83 & & 6 & 86 \\
\hline $\mathrm{llb}$ & & 1 & 17 & & 1 & 14 \\
\hline
\end{tabular}

Type I and II synaptic glomeruli in lamina II were identified in sections from the lumbar enlargement of wild-type mice ( $n=5$ mice). The presence or absence of postsynaptic immunolabeling for GIRK1 and GIRK2 within the identified synaptic glomeruli was then documented. The total number of type I and II glomeruli analyzed for each labeling experiment is listed (Total), as is the number positive and frequency of glomeruli positive for a given GIRK subunit. Note that $\sim 90 \%$ of type I glomeruli identified in this study exhibited labeling for GIRK1 and GIRK2, whereas $<10 \%$ of type II glomeruli were GIRK positive. Glomeruli positive for a given GIRK subunit were then further characterized (la or lb, Ila or Illb) on the basis of morphological criteria (see Materials and Methods). GIRK subunits were relatively evenly distributed in type la and Ib glomeruli; the relatively few type II glomeruli exhibiting GIRK subunit labeling tended to be type lla structures. opioid antinociception, however, it is crucial to identify the type of PAF input to GIRK-containing channels in lamina II. To this end, we used immunoelectron microscopy and ultrastructural analysis to characterize the morphology of synaptic glomeruli exhibiting GIRK subunit labeling in an effort to gain insight into the PAF input to GIRK-containing lamina II neurons. Despite representing only a fraction of the total synapses in lamina II, the central terminals of PAFs and the associated synaptic glomeruli are the most prominent structures in the SDH (Rethelyi et al., 1982; Ribiero-da-Silva and Coimbra, 1982). Furthermore, synaptic glomeruli associated with $\mathrm{C}$ fibers (type I) and $\mathrm{A} \delta$ fibers (type II) exhibit unique and distinct morphological features (Knyihar-Csillik et al., 1982; Ribiero-da-Silva and Coimbra, 1982; Coimbra et al., 1984).

Although most of the postsynaptic labeling for GIRK1 (576 of 873 immunoparticles, 66\%) and GIRK2 (610 of 911 immunoparticles, $67 \%$ ) seen in sections from wild-type mice was found in nonglomerular dendrites, both subunits were also clearly present in synaptic glomeruli (Fig. 7). Results from multiple control experiments, including experiments with tissue from GIRK knockout mice, validated the observed immunoreactivity (data not shown). The overwhelming majority ( $\sim 90 \%)$ of type I glomeruli documented in this study exhibited GIRK1 or GIRK2 labeling (Table 1). In contrast, only a small fraction $(<10 \%)$ of type II glomeruli identified in lamina II exhibited labeling for either GIRK1 or GIRK2. Type I glomeruli could be subdivided into type Ia and type Ib structures on the basis of neurotransmitter vesicle morphology (see Materials and Methods); GIRK subunit labeling was distributed relatively evenly among both subtypes, suggesting that GIRK-containing lamina II neurons receive input from both peptidergic and nonpeptidergic $\mathrm{C}$ fibers.

\section{Discussion}

Although lamina II of the spinal cord dorsal horn is thought to represent an important neuroanatomical substrate for nociception and opioid analgesia, the functional, molecular, and neurochemical profiles of the neurons in this sublamina are not well understood. Furthermore, there are few, if any, clear correlations between lamina II interneuron subpopulations and physiological outputs. Here, we show that GIRK channels formed by GIRK1 and GIRK2 subunits are found in excitatory interneurons in lamina II of the mouse spinal cord, where they serve as direct downstream targets of activated MOR. GIRK channels are also found in a subpopulation of lamina II interneurons that responds to the $\mathrm{GABA}_{\mathrm{B}}$ receptor-selective agonist baclofen but not DAMGO. Finally, based on morphological analysis, we conclude that $\mathrm{C}$ fibers but not $\mathrm{A} \delta$ fibers impinge primarily on GIRK-containing lamina II neurons.

Lamina II neurons responding to DAMGO, together with those responding to baclofen but not DAMGO, accounted for $>90 \%$ of the wild-type neurons profiled in this study. The existence of a third subpopulation of GIRK-containing lamina II neurons is suggested by the overlapping but distinct cellular distributions of MOR and $\mathrm{GABA}_{\mathrm{B}}$ in lamina II, and by the fact that some but not all of the DAMGO-responsive neurons also responded to baclofen. In light of published observations that preincubation with DAMGO decreased the magnitude of baclofen-induced GIRK current in expression systems by $\sim 50 \%$ (Mutneja et al., 2005), we chose not to categorize DAMGO- 
responsive neurons on the basis of their subsequent baclofen response in this study. Indeed, the lack of a baclofen response after DAMGO application could reflect either the lack of $\mathrm{GABA}_{\mathrm{B}}$ receptors or prominent heterologous desensitization of the baclofeninduced current response. Thus, we cannot rule out the possibility that all lamina II neurons expressing MOR also express the $\mathrm{GABA}_{\mathrm{B}}$ receptor and that both are capable of activating GIRK channels formed by GIRK1 and GIRK2 subunits.

Two intriguing correlations were noted in this study. First, DAMGO-responsive neurons and baclofen-responsive neurons were more hyperpolarized than nonresponsive neurons. Given the impact of GIRK subunit ablation on resting membrane potential in these neurons, it seems reasonable to conclude that tonic GIRK activity contributes to resting membrane potential of the DAMGO- and baclofen-responsive neurons. Second, a relationship between apparent whole-cell capacitance and DAMGO sensitivity response was noted. Measuring true whole-cell capacitance values in slice preparations is complicated because of the potential for electronic coupling and of the impact of slice orientation on dendritic arbors. Nevertheless, with the transverse slice orientation, we found that large $(>50 \mathrm{pF})$ apparent capacitance values were excellent predictors of DAMGO-induced current responses in lamina II neurons. Future electrophysiological studies involving biocytin or Lucifer yellow will provide important insights into the morphology and projections of the distinct subpopulations of lamina II neurons reported here.

Neuronal GIRK channels are homotetrameric and heterotetrameric complexes formed primarily by GIRK1, GIRK2, and GIRK3 subunits (Koyrakh et al., 2005). Despite the broad distribution of GIRK3 mRNA in the CNS (Karschin et al., 1996), it has proven difficult to discern the contribution of the GIRK3 subunit to neuronal GIRK channels. Previous studies have shown that GIRK3 ablation alone does not correlate with decreased neurotransmitter-gated GIRK currents in hippocampal CA1 neurons or in locus ceruleus neurons (Torrecilla et al., 2002; Koyrakh et al., 2005). In these neuron populations, however, an apparent contribution of GIRK3 to channel formation and function is gleaned by comparisons of neurotransmitter-induced currents measured in neurons from GIRK2 knock-out and GIRK2/ GIRK3 double knock-out mice. In contrast, there is little evidence to support a role for GIRK3 in the formation of GIRK channels in mouse lamina II neurons. As shown previously, the level of GIRK3 protein in crude spinal cord membrane protein samples is lower than that seen in samples from the brain (Marker et al., 2004). More importantly, GIRK3 ablation had no effect on the magnitude of DAMGO- or baclofen-induced currents, and the simultaneous ablation of GIRK2 and GIRK3 produced a phenotype equivalent to that measured in neurons from GIRK2 knock-out mice. Thus, evidence presented to date argues that the GIRK channel mediating the inhibitory and antinociceptive effects of opioids in the spinal cord is formed by GIRK1 and/or GIRK2 with little or no contribution from GIRK3.

The presence of DAMGO-induced currents in lamina II neurons from GIRK2 knock-out and GIRK2/GIRK3 double knock-out mice indicates that MOR activation leads to the modulation of multiple postsynaptic currents in the spinal cord. Complex currents consisting of GIRK-dependent and GIRK-independent components have been reported in hippocampal CA1 neurons, locus ceruleus neurons, and dopamine neurons of the ventral tegmental area and substantia nigra. Unlike the situation in these neuron populations, however, the lack of GIRK2 (or GIRK1) in spinal cord neurons leads to significant decreases in both the frequency of occurrence and amplitude of DAMGO-induced currents. Indeed, $<10 \%$ of lamina II neu- rons from GIRK2 knock-out mice respond to DAMGO compared with $40 \%$ of wild-type lamina II neurons. Thus, it would appear that only a subset of GIRK-containing lamina II neurons possess the non-GIRK conductance(s) modulated by MOR-dependent signaling. Possible channels underlying this non-GIRK component, based on precedent from other studies, include voltage-gated $\mathrm{K}^{+}$channels and a cAMP-dependent $\mathrm{Na}^{+}$current (Torrecilla et al., 2002; Cruz et al., 2004; Koyrakh et al., 2005).

Previously, we found that GIRK subunits are enriched in lamina IIo of the mouse spinal cord. This enrichment is intriguing because a relatively large proportion of lamina IIo neurons are activated by noxious stimuli (Light and Perl, 1979; Bennett et al., 1980; Ji et al., 1999). Although labeling studies consistently indicate that different PAF subcategories terminate preferentially in distinct regions of lamina II, there is no strong consensus as to the category of PAF that preferentially innervates lamina IIo. Substance P labeling has been found to be intense in lamina IIo, suggesting that peptidergic PAFs make considerable synaptic input to this sublamina (Doly et al., 2004). In addition, some studies have shown that lamina IIi is prominently labeled by isolectin-B4 (IB4), an $\alpha$-D-galactose-binding lectin from Griffonia (Bandeiraea) simplicifolia that preferentially labels nonpeptidergic fine-caliber PAFs (Swett and Woolf, 1985; Silverman and Kruger, 1988a,b; Molliver et al., 1997; Bennett et al., 1998). Other groups, however, have shown termination of IB4-reactive fibers in both laminas IIo and IIi (Wang et al., 1994), whereas a relatively recent transganglionic labeling study demonstrated prominent labeling of mouse lamina IIo with IB4 (Woodbury et al., 2000).

Although correlations between marker labeling and PAF subtypes are often complicated, there is general agreement that the morphological profile of synaptic glomeruli, at least in the $\mathrm{SDH}$, is a strong predictor of PAF subtype. Accordingly, the prevalence of GIRK subunit labeling within type I glomeruli, together with the relative lack of GIRK labeling seen in type II glomerular structures, suggests that GIRK-containing lamina II neurons in the mouse spinal cord primarily receive $C$ fiber input. Ultrastructural evidence also indicates that the $\mathrm{C}$ fiber input to GIRK-containing lamina II neurons could be either peptidergic or nonpeptidergic. Despite this evidence, it is not possible to rule out completely the innervation of GIRK-containing lamina II neurons by A $\delta$ fibers, because significant axonal branching of fine-caliber PAFs occurs within the SDH (Sugiura et al., 1986) and synaptic glomeruli represent only a fraction of total synapses in this region of the spinal cord. Nevertheless, these data represent the first insights into the pro-nociceptive circuitry within which spinal GIRK channels function.

In summary, we have shown that GIRK channels formed by GIRK1 and GIRK2 mediate the postsynaptic inhibitory effects of $\mathrm{MOR}$ and $\mathrm{GABA}_{\mathrm{B}}$ receptor agonists in multiple distinct populations of spinal cord lamina II interneurons. The physiological roles of the lamina II interneuron populations identified in this study remain to be determined. Of particular interest are the respective contributions of the baclofen-responsive and the DAMGO-responsive lamina II neurons to intrathecal antinociception. Our observations suggest that overlapping but distinct spinal circuits mediate the antinociceptive effects of intrathecal opioids and baclofen and may explain why modulating both circuits in intrathecal drug therapy is most effective for treating certain patients and certain types of pain (Slonimski et al., 2004).

\section{References}

Abbadie C, Pasternak G, Aicher S (2001) Presynaptic localization of the carboxy-terminus epitopes of the mu opioid receptor splice variants MOR-1C and MOR-1D in the superficial laminae of the rat spinal cord. Neuroscience 106:833-842. 
Arvidsson U, Dado R, Riedl M, Lee J, Law P, Loh H, Elde R, Wessendorf M (1995) Distribution and targeting of a $\mu$-opioid receptor (MOR1) in brain and spinal cord. J Neurosci 15:3328-3341.

Bennett D, Michael G, Ramachandran N, Munson J, Averill S, Yan Q, McMahon S, Priestly J (1998) A distinct subgroup of small DRG cells express GDNF receptor components and GDNF is protective for these neurons after nerve injury. J Neurosci 18:3059-3072.

Bennett GJ, Abdelmoumene M, Hayashi H, Dubner R (1980) Physiology and morphology of substantia gelatinosa neurons intracellularly stained with horseradish peroxidase. J Comp Neurol 194:809-827.

Bettahi I, Marker CL, Roman MI, Wickman K (2002) Contribution of the Kir3.1 subunit to the muscarinic-gated atrial potassium channel $\mathrm{I}_{\mathrm{KACh}}$. J Biol Chem 277:48282-48288.

Coimbra A, Ribiero-da-Silva A, Pignatelli D (1984) Effects of dorsal rhizotomy on the several types of primary afferent terminals in laminae I-III of the rat spinal cord. An electron microscope study. Anat Embryol (Berl) 170:279-287.

Cruz HG, Ivanova T, Lunn ML, Stoffel M, Slesinger PA, Luscher C (2004) Bi-directional effects of $\mathrm{GABA}(\mathrm{B})$ receptor agonists on the mesolimbic dopamine system. Nat Neurosci 7:153-159.

Doly S, Madeira A, Fischer J, Brisorgueil M-J, Daval G, Bernard R, Verge D, Conrath M (2004) The 5-HT2A receptor is widely distributed in the rat spinal cord and mainly localized at the plasma membrane of postsynaptic neurons. J Comp Neurol 472:496-511.

Eckert III WA, Light AR (2002) Hyperpolarization of substantia gelatinosa neurons evoked by mu-, kappa-, delta 1-, and delta 2 -selective opioids. J Pain 3:115-125.

Gerke M, Plenderleith M (2004) Ultrastructural analysis of the central terminals of primary sensory neurones labelled by transganglionic transport of bandeiraea simplicifolia I-Isolectin B4. Neuroscience 127:165-175.

Ji RR, Baba H, Brenner GJ, Woolf CJ (1999) Nociceptive-specific activation of ERK in spinal neurons contributes to pain hypersensitivity. Nat Neurosci 2:1114-1119.

Julius D, Basbaum AI (2001) Molecular mechanisms of nociception. Nature 413:203-210

Karschin C, Dissmann E, Stuhmer W, Karschin A (1996) IRK(1-3) and GIRK(1-4) inwardly rectifying $\mathrm{K}^{+}$channel mRNAs are differentially expressed in the adult rat brain. J Neurosci 16:3559-3570.

Knyihar-Csillik E, Csillik B, Rakic P (1982) Periterminal synaptology of dorsal root glomerular terminals in the substantia gelatinosa of the spinal cord in the rhesus monkey. J Comp Neurol 210:376-399.

Koyrakh L, Lujan R, Colon J, Karschin C, Kurachi Y, Karschin A, Wickman K (2005) Molecular and cellular diversity of neuronal G-protein-gated potassium channels. J Neurosci 25:11468-11478.

Krapivinsky G, Gordon EA, Wickman K, Velimirovic B, Krapivinsky L, Clapham DE (1995) The G-protein-gated atrial $\mathrm{K}^{+}$channel $\mathrm{I}_{\mathrm{KACh}}$ is a heteromultimer of two inwardly rectifying $\mathrm{K}^{+}$-channel proteins. Nature 374:135-141.

Kulik A, Vida I, Lujan R, Haas CA, Lopez-Bendito G, Shigemoto R, Frotscher $\mathrm{M}$ (2003) Subcellular localization of metabotropic $\mathrm{GABA}_{\mathrm{B}}$ receptor subunits $\mathrm{GABA}_{\mathrm{B} 1 \mathrm{a} / \mathrm{b}}$ and $\mathrm{GABA}_{\mathrm{B} 2}$ in the rat hippocampus. J Neurosci 23:11026-11035.

Kumazawa T, Perl ER (1978) Excitation of marginal and substantia gelatinosa neurons in the primate spinal cord: indications of their place in dorsal horn functional organization. J Comp Neurol 177:417-434.

Light AR, Perl ER (1979) Spinal termination of functionally identified primary afferent neurons with slowly conducting myelinated fibers. J Comp Neurol 186:133-150.

Light AR, Trevino DL, Perl ER (1979) Morphological features of functionally defined neurons in the marginal zone and substantia gelatinosa of the spinal dorsal horn. J Comp Neurol 186:151-171.

Lopez-Bendito G, Shigemoto R, Kulik A, Vida I, Fairen A, Lujan R (2004) Distribution of metabotropic GABA receptor subunits GABAB1a/b and GABAB2 in the rat hippocampus during prenatal and postnatal development. Hippocampus 14:836-848.

Lu C-R, Hwang S, Phend K, Rustioni A, Valtschanoff J (2002) Primary afferent terminals in spinal cord express presynaptic AMPA receptors. J Neurosci 22:9522-9529.

Lujan R, Shigemoto R (2006) Localization of metabotropic GABA receptor subunits $\mathrm{GABAB} 1$ and $\mathrm{GABAB} 2$ relative to synaptic sites in the rat developing cerebellum. Eur J Neurosci 23:1479-1490.

Lujan R, Shigemoto R, Kulik A, Juiz JM (2004) Localization of the GABAB receptor $1 \mathrm{a} / \mathrm{b}$ subunit relative to glutamatergic synapses in the dorsal cochlear nucleus of the rat. J Comp Neurol 475:36-46.

Marker CL, Stoffel M, Wickman K (2004) Spinal G-protein-gated K ${ }^{+}$channels formed by GIRK1 and GIRK2 subunits modulate thermal nociception and contribute to morphine analgesia. J Neurosci 24:2806-2812.

Marker CL, Lujan R, Loh HH, Wickman K (2005) Spinal G-protein-gated potassium channels contribute in a dose-dependent manner to the analgesic effect of $\mu$ - and $\delta$ - but not $\kappa$-opioids. J Neurosci 25:3551-3559.

Millan MJ (1999) The induction of pain: an integrative review. Prog Neurobiol 57:1-164.

Molliver DC, Wright DE, Leitner ML, Parsadanian AS, Doster K, Wen D, Yan Q, Snider WD (1997) IB4-binding DRG neurons switch from NGF to GDNF dependence in early postnatal life. Neuron 19:849-861.

Mutneja M, Berton F, Suen KF, Luscher C, Slesinger PA (2005) Endogenous RGS proteins enhance acute desensitization of $\mathrm{GABA}(\mathrm{B})$ receptoractivated GIRK currents in HEK-293T cells. Pflügers Arch 450:61-73.

Panzanelli P, Lopez-Bendito G, Lujan R, Sassoe-Pognetto M (2004) Localization and developmental expression of $\mathrm{GABA}(\mathrm{B})$ receptors in the rat olfactory bulb. J Neurocytol 33:87-99.

Peters A, Palay S, Webster H (1991) The fine structure of the nervous system: neurons and their supporting cells. New York: Oxford UP.

Rethelyi M, Szentagothai J (1969) The large synaptic complexes of the substantia gelatinosa. Exp Brain Res 7:258-274.

Rethelyi M, Light AR, Perl ER (1982) Synaptic complexes formed by functionally defined primary afferent units with fine myelinated fibers. J Comp Neurol 207:381-393.

Ribiero-da-Silva A, Coimbra A (1982) Two types of synaptic glomeruli and their distribution of lamina I-III of the rat spinal cord. J Comp Neuro 209:176-186.

Schneider SP, Eckert III WA, Light AR (1998) Opioid-activated postsynaptic, inward rectifying potassium currents in whole cell recordings in substantia gelatinosa neurons. J Neurophysiol 80:2954-2962.

Signorini S, Liao YJ, Duncan SA, Jan LY, Stoffel M (1997) Normal cerebellar development but susceptibility to seizures in mice lacking $\mathrm{G}$ protein-coupled, inwardly rectifying $\mathrm{K}^{+}$channel GIRK2. Proc Natl Acad Sci USA 94:923-927.

Silverman JD, Kruger L (1988a) Acid phosphatase as a selective marker for a class of small sensory ganglion cells in several mammals: spinal cord distribution, histochemical properties, and relation to fluoride-resistant acid phosphatase (FRAP) of rodents. Somatosens Res 5:219-246.

Silverman JD, Kruger L (1988b) Lectin and neuropeptide labeling of separate populations of dorsal root ganglion neurons and associated nociceptor thin axons in rat testis and cornea whole-mount preparations. Somatosens Res 5:259-267.

Slonimski M, Abram SE, Zuniga RE (2004) Intrathecal baclofen in pain management. Reg Anesth Pain Med 29:269-276.

Spike R, Kerr R, Maxwell DJ, Todd AJ (1998) GluR1 and GluR2/3 subunits of the AMPA-type glutamate receptor are associated with particular types of neurone in laminae I-III of the spinal dorsal horn of the rat. Eur J Neurosci 10:324-333.

Spike R, Puskar Z, Sakamoto H, Stewart W, Watt C, Todd A (2002) MOR1 -immunoreactive neurons in the dorsal horn of the rat spinal cord: evidence for nonsynaptic innervation by substance $\mathrm{P}$-containing primary afferents and for selective activation by noxious thermal stimuli. Eur J Neurosci 15:1306-1316.

Sugiura Y, Lee CL, Perl ER (1986) Central projections of identified, unmyelinated (C) afferent fibers innervating mammalian skin. Science 234:358-361.

Swett J, Woolf C (1985) The somatotopic organization of primary afferent terminals in the superficial laminae of the dorsal horn of the rat spinal cord. J Comp Neurol 231:66-77.

Todd A, Spike R (1993) The localization of classical transmitters and neuropeptides within neurons in lamina I-III of the mammalian spinal dorsal horn. Prog Neurobiol 41:609-646.

Torrecilla M, Marker CL, Cintora SC, Stoffel M, Williams JT, Wickman K (2002) G-protein-gated potassium channels containing Kir3.2 and Kir3.3 subunits mediate the acute inhibitory effects of opioids on locus ceruleus neurons. J Neurosci 22:4328-4334.

Wang H, Rivero-Melian C, Robertson B, Grant G (1994) Transganglionic transport and binding of the isolectin B4 from Griffonia simplicifolia I in rat primary sensory neurons. Neuroscience 62:539-551.

Woodbury CJ, Ritter AM, Koerber HR (2000) On the problem of lamination in the superficial dorsal horn of mammals: a reappraisal of the substantia gelatinosa in postnatal life. J Comp Neurol 417:88-102. 